\title{
RUSSIA-ASEAN SUMMIT 2016: IMPROVEMENT FOR THE BETTER STRATEGIC PARTNERSHIP
}

\author{
Juniar Laraswanda Umagapi \\ Political Analysis and Public Policy of Social Science Faculty \\ National Research University Higher School of Economics Moscow Russia \\ laraswanda17@gmail.com
}

\begin{abstract}
This article tries to elaborate the impact for the cooperation between ASEAN-Russia in economic and political security. How the ways to increase their bilateral relations and bring positive impacts for both countries. ASEAN is often regarded as the paragon case of successful regional security cooperation and attributes its achievement to economy, social—cultural and political-security. In the recent years, ASEAN try to create many external relations with another country and Russia is one of them. ASEAN want to make a mutual relationship with others and solve the regional issue happen in many countries. Economy and political security will be the main issue for this cooperation. ASEAN and Russia start their bilateral relation for a long time ago but economic relations like trade is still low but they try hard to progress. After ASEAN summit 2016 in Sochi, Russia on 1921 May a lot of agreement have been signed and people looking forward for the impact of this partnership.
\end{abstract}

Keywords: ASEAN; strategic partnership; security; economy; political; ASEAN-Russia Summit 2016; sochi

\begin{abstract}
Abstrak
Artikel ini mencoba untuk menguraikan dampak kerjasama antara ASEAN-Rusia dalam bidang keamanan ,ekonomi dan politik. Bagaimana cara meningkatkan hubungan bilateral antar kedua negara dan membawa dampak positif bagi kedua negara. ASEAN sering dianggap sebagai kasus paragon dari suksesnya kerjasama keamanan regional dan memberikan kontribusi prestasinya di bidang ekonomi, sosial budaya dan keamanan politik. Dalam beberapa tahun terakhir, ASEAN mencoba menciptakan banyak hubungan eksternal dengan negara lain dan Rusia adalah salah satunya. ASEAN ingin menjalin hubungan timbal balik dengan negara-negara lain dan memecahkan masalah regional yang terjadi di banyak negara. Ekonomi dan keamanan politik akan menjadi isu utama untuk kerja sama ini. ASEAN dan Rusia memulai hubungan bilateral mereka untuk waktu yang lama namun hubungan ekonomi seperti perdagangan masih rendah karena itu mereka berusaha keras untuk berkembang. Setelah KTT ASEAN 2016 di Sochi, Rusia pada tanggal 19-21 Mei banyak kesepakatan telah ditandatangani dan banyak pihak menantikan dampak dari kemitraan ini.
\end{abstract}

Kata Kunci: ASEAN; kemitraan strategis; keamanan; ekonomi: politik; KTT ASEAN-Rusia 2016; sochi

\section{Introduction}

ASEAN as the regional international organization try to create a mutual understanding through same vision and mission with another country around the world. Since the establishment of ASEAN in 1967, this international organization had a goal to create regional security in Southeast Asia, so now ASEAN is faced by a major organizational-structural change on geopolitical order in Southeast Asia that will threaten not only security of ASEAN member countries but also all country in the world. The ASEAN recently is more going into significant change on geopolitical order either in the Southeast Asia region or international order. Upheavals situation which made the world recently become a serious concern for ASEAN which also related to political and security issues that occurred such as terrorism, security in Asia-Pacific and cross-border crimes created unstable relationship among ASEAN member states, conflicts which related to claim border and the intervention of external forces as an overview of the geopolitical order changes in Southeast Asia today.

South East Asian countries always want to be main parties towards the peace 
building. ASEAN member countries always facing the same problem in their regional so they need a cooperation with other countries which is have the same mission also to spread the peace and solve the conflict inside or outside the country. Russia as the world largest country in the world in the history is always be main party for many wars and conflicts until now. Russia shows to the world about their mission to stop terrorism and conflict and it is also same with the mission of some member countries of ASEAN.

The history of Russia is very interesting as their effort to build this country itself. After the collapse of the Soviet Union, the government of the Russian Federation headed by President Boris Yeltsin in 1991. In that time, they are struggle with their economic growth but slowly it is getting better. In the presidential elections in March 2000, Putin was elected President of the Russian Federation. ${ }^{1}$ Putin seeks to restore Russia as a powerful and influential country in the world. In the 2000s the government made a series of social and economic reforms, such as taxation, land, pensions, banking, labour, electricity and rail transport. At the time, the stability of the Russian economy occurs state budget, GDP growth, the growth of industrial and agricultural production, construction, real incomes of the population and a decrease in inflation.

\section{Theory and/or concept}

ASEAN acknowledges Russia as one of the key players in the Asia Pacific region. ASEAN sees Russia as a strategic partner as Russia is one of the five recognized Nuclear Weapon States, a member of the G8, a permanent member of the UNSC, and a member of many other major regional and international organizations. This strategic

\footnotetext{
${ }^{1}$ Wikipedia "History of Russia 1991-present" was last edited on 6 September 2017, at 15:09
}

importance brought Russia to the status of a full Dialogue Partner of ASEAN in 1996.

We can proudly have said the cooperation between Russia-ASEAN is getting tighter and a lot of signed agreement between both parties. Russia as the main actor in Eurasia Economic Union (EAEU) and ASEAN play an important role also in the region, after Vietnam as the member of ASEAN sign a free trade agreement with EAEU, many parties think that it will give a big influence for their economic relation between ASEAN and EAEU and later al countries in ASEAN can sign Free Trade Agreement with Russia or even EAEU itself.

Cooperation between each country for direct or indirect will create mutual benefits for their economy progress. From the first Russia still maintain the relation with west side like European Union but after US create a sanction for anti-Russia the relations become not closed anymore so Russia chose to back off and looking for another alliance which is the eastern side. ASEAN and Russia have dialogue partnership until now and active for the dialogues regarding the recent issue and the diplomatic relationship between ASEAN and Russia laws getting bigger every time. ASEAN acknowledges Russia as one of the key players in the Asia Pacific region. 
Table 1. ASEAN Trade Dependency

Total Trade with Selected Partners

\begin{tabular}{lllllll}
\hline Country & $\mathbf{2 0 0 7}$ & $\mathbf{2 0 0 9}$ & $\mathbf{2 0 1 1}$ & $\mathbf{2 0 1 2}$ & $\mathbf{2 0 1 3}$ & $\mathbf{2 0 1 4}$ \\
$\begin{array}{l}\text { In USS } \\
\text { Million }\end{array}$ & & & & & \\
\hline $\begin{array}{l}\text { Intra- } \\
\text { ASEAN }\end{array}$ & 401,914 & 376,213 & 598,377 & 602,048 & 608,558 & 608,207 \\
Australia & 41,974 & 43,848 & 59,685 & 69,499 & 68,058 & 70,373 \\
Canada & 9,496 & 9,020 & 10,774 & 12,335 & 13,155 & 13,155 \\
China & 171,089 & 178,223 & 280,150 & 319,485 & 350,508 & 366,526 \\
EU-28 & 187,307 & 171,431 & 234,621 & 242,599 & 246,228 & 248,308 \\
India & 37,243 & 39,075 & 68,191 & 71,816 & 67,862 & 67,708 \\
Japan & 173,056 & 160,918 & 273,867 & 262,884 & 240,767 & 229,042 \\
South & 61,209 & 74,771 & 124,403 & 131,030 & 134,963 & 131,439 \\
Korea & & & & & & \\
New & 5,797 & 5,381 & 8,244 & 9,225 & 9,785 & 10,708 \\
Zealand & & & & & & \\
Russia & 5,401 & 6,769 & 13,927 & 18,158 & 19,950 & 22,543 \\
US & 178,189 & 148,780 & 198,767 & 200,027 & 206,855 & 212,429 \\
\hline
\end{tabular}

Note: $1 /$ Based on the 2014 levels, in USS million

Source: ASEAN Trade Statistics Database, as of 21 December 2015 
If we see the table, Indonesia most top selected partner are China, Japan, EU and US that is why both parties know that both of them still not the priority to each other but until now it is still progressing positively as they sign many agreement and both of the parties also move forward in the free trade agreement for example Vietnam. It is still difficult to be main partnership but they are still trying to make a good relationship especially after ASEANRussia Summit in Sochi last year.

\section{Political and Security Cooperation}

Political and Security Cooperation also are the important issue in ASEAN and Russia itself, many conflicts happen in ASEAN and how politics can be the main problem or maybe the main instrument to solve many conflicts in ASEAN or Russia itself. Political and Security will be the main issue for some particular countries in ASEAN such as Myanmar, Thailand, and Indonesia. Their regional conflict will affect the sustainability for their own regional situation. Russia is famous with their security and military aspect so ASEAN will be get advantage if make a military and security relation with Russia.

ASEAN and Russia maintain good political and security relations. A milestone in ASEAN-Russia dialogue relations was when Russia acceded to the Treaty of Amity and Cooperation in Southeast Asia (TAC) on 29 November 2004. Russia's accession to the TAC reflects her strong commitment to regional peace, stability and a significant contribution to the TAC as an important code of conduct governing inter-states relations. ${ }^{2}$

2 ASEAN-Russia Dialogue Relations from http://asean.org/?static_post=asean-russia-dialoguerelations was published on 15 May 2012
A security dialogue involving Russia and the grouping could help ease tensions in the South China Sea, Taiwan Strait and the Korean peninsula, he added." Politically, the two entities have plenty in common, for they share similar visions for the Asia-Pacific region. Russia has recognized that ASEAN constitutes the "backbone of regional order", both within Southeast Asia and the larger Asia-Pacific region. On its part, ASEAN has affirmed its support for Russia's participation in regional political and economic structures. ${ }^{4}$ Russian sources are also keen to emphasize that both Russia and ASEAN hold a vision of a polycentric regional and global order. $^{5}$ For example Indonesia, a few days ago the Chairman of the board of Russia Federation Valentina Matvienko have a meeting with the head of regional representative council of Indonesia Irman Gusman and they want to make a military cooperation like establish technical service centre in Indonesia and the possibility of the Indonesian military personnel to study at military schools in Russia. Indonesia also believes and agrees that Russia have important rule for the security in Asia-Pacific.

ASEAN needs Russia and other rising powers to prevent both China and the United States from dominating the region as they wish. The problem of South China Sea that involved mostly the member countries of ASEAN and China as well make them understood that the

\footnotetext{
${ }^{3}$ Sergei Lavrov "Russia and ASEAN can achieve a great deal together" from https://interaffairs.ru/i/pdf_asean/2.pdf special issue on 2010

4 Rangismaporn, P. (2009), 'Russia's Search for Influence in Southeast Asia', Asian Survey 49 (5), 786-808.

5 Sergei Lavrov "Russia and ASEAN can achieve a great deal together" from https://interaffairs.ru/i/pdf_asean/2.pdf special issue on 2010
} 
situation could be worse than that also. Aside from being a major power, Russia could also play a crucial role in establishing the security architecture due to its foreign policy agenda in the region. According to Anton Tsvetov of the Russian International Affairs Council, the AsiaPacific in general, and the South China Sea in particular, are not priorities for Russian foreign policy. The major concern of Russian policy in the region is its bilateral relationships with Vietnam and China. Vietnam is one of largest recipients of Russian arms while China is the largest trading partner in terms of investment and trade. Thus, Russian involvement in the AsiaPacific security architecture might challenge the existing relationship among the three countries. ${ }^{6}$

\section{ASEAN-Russia Summit 2016}

By the prediction of Russian diplomatic and politics side that the gross domestic product of ASEAN member-states stands at about $\$ 3.5$ trillion today and is expected to reach $\$ 4$ trillion by 2020. ASEAN is becoming an increasingly attractive area for foreign investments, which grew by $16 \%$ in 2014 to over $\$ 136$ billion $^{7}$. Beside the economic issue of the GDP of ASEAN which always increasing every year and its one of the positive side for all ASEAN external cooperation and one of the main partners is Russia.

The last ASEAN-Russia summit in Sochi on 19-21 May give a big contribution for both countries. It will be a great event to everybody as the representative of ASEAN and

6 Mohammad Rosyidin "ASEAN and Russia: Creating a New Security Architecture" access on https://thediplomat.com/2016/06/asean-and-russiacreating-a-new-security-architecture/ was published on 01 June 2016

7 Aleksey Druzhinin TASS "Putin: Russia-ASEAN Summit to help solve regional security problems" http://tass.com/politics/874929 was published on May $11,2016,13: 17$
Russia side. This international conference will be a big event for Russia itself in 2016. Under the motto "Towards Mutually Advantageous Strategic Partnership "The heads of state reaffirmed their commitment to the further development of multilateral cooperation on the principles of equality, mutual benefit and common responsibility for promoting peace, stability, security and prosperity in the AsiaPacific Region.

In this big event, it is a chance for every leader in all 11 countries to increase their multilateral cooperation. The issue of connectivity among ASEAN member countries will be the main argument. The ASEAN chairmanship rotates annually and currently Laos chairs this organization. Oudet Souvannayong as the chairman of ASEAN business advisory council and executive vice president of Lao National Chamber of Commerce and Industry on 17 May 2016 deliver his public lecture in MGIMO explain briefly about the position of ASEAN for Russia. As one of the main partner for Russia side ASEAN play important role as the strategic partnership in the economic, social and culture. Entrepreneurship also will be the focus that's why ASEAN-Russia discussed the future trade investment. He also makes a statement to increase women entrepreneurship as the focus of gender equality in ASEAN mission right now. The problem only in the mental stability and the paradigm of people, Asian people have the problem of mentality risk, they are afraid to be a businessman even they know that the future of free trade make the business sector will increase and as the main potential sector to increase the economic sector but the focused is not only in the mentality of fail to do business and mentality risk.

Russia seems to view ASEAN as an opportunity for economic expansion. Moscow apparently sought economic benefits from 
expanded ties with ASEAN — one of the largest international groupings — with a combined population of more than 600 million people. During the summit, Putin repeatedly called attention to the fact that Russia's trade with ASEAN countries amounted to only $\$ 13.7$ billion in 2015, or well below the potential trade on both sides. Total mutual investments were also pegged at $\$ 11$ billion, a number also described as too low. ${ }^{8}$

In the aspect of oil and gas, the petroleum industry in Russia is one of the largest in the world. Russia has the largest reserves and is the largest exporter of natural gas. In ASEAN side Many Southeast Asian countries produce fossil fuels. While gas production grows, some oil exporting countries now become importers to meet a rising internal demand. The strongest contributions such are Thailand, Malaysia and Indonesia. Russia is prepared to supply oil to ASEAN member-states, Energy Minister Alexander Novak said at the summit on May 20. (Live Ruptly TV Press Conference/ Russian Energy Minister Alexander Novak)

Russia's planned mega-projects in ASEAN seemed to be concentrated in Indonesia. Following a meeting with Joko Widodo on May 18, Putin confirmed Russian interest in building a 190-kilometer railway transport facility in Kalimantan at an estimated cost of $\$ 1.9$ billion. Russian officials also mentioned plans by energy giants Rosneft and Zarubezhneft to build a \$13 billion refinery in Java. Russia's Inter RAO also planned to build a $\$ 2.8$ billion $1.8 \mathrm{GW}$ thermopower plant in Indonesia. $^{9}$

\footnotetext{
${ }^{8}$ Sergei Blagov "Sochi ASEAN Summit: Russia eyes economic expansion in SEAsia" access from http://www.atimes.com/article/sochi-asean-summitrussia-eyes-economic-expansion-in-southeast-asia/ was published on MAY 23, 2016 10:21 AM

${ }^{9}$ Ibid
}

Russia and Indonesia sign the memorandum of cooperation for their bilateral relations. Jokowi state that they agree to increase cooperation investment in various fields, as culture maritime, agricultural, and infrastructure. We are interested in the development and the continuation of the construction of a railroad track and port in Kalimantan, as well as projects of oil. In the railway section who they want to build a longest railway in Kalimantan that is also the reason why Russia built up the cooperation with Indonesian in the term of education. For the railway project the government of Russia give scholarship for 50 students in Kalimantan every year for study railway as the prediction of railway construction in Kalimantan will finish in 2019. This will be a good option for increase the human resource in this field so they can be a good source when this railway finish. Russia also help Indonesia so much in the security aspect, when we have a problem with burning forest in Kalimantan and the hazes spread around to the neighbour country Russia send their plane to stop the fire.

As we understand that Russia right now in the move and try hard to encounter the terrorism issue, and that's also the reason they have a clash with Turkey in the past and now Russia trying to ask all the countries in ASEAN to do the same to stop terrorism. Maybe this is also will give the impact for ASEAN member countries external cooperation with the west countries and maybe will make the tension between west and east but how we can see this in the positive side that many countries already be a victim of terrorism so we must strong enough and build as many parties to have the same mission to encounter terrorism. The Russian president Vladimir Putin state that "The summit's agenda covers a wide range of issues related to improving the architecture of regional security, searching for new ways of countering the growing threats of international terrorism, 
violent extremism and trans-national crime" as his noted and of course strengthen peace and stability in Southeast Asia. Trust and connectivity are the aspect that two sides must get it so the fair multilateral cooperation can be success and we hope as ASEAN young generation that this cooperation will make a good impact to all sectors in all countries. One was a ground-breaking ceremony for a major cooperative agricultural project near Moscow attended by Vietnamese Prime Minister Nguyen Xuan Phuc. Investment on the project could hit $\$ 2.7$ billion. $^{10}$

\section{Solution}

For answer the question about can Russia-ASEAN cooperation have positive impact on the economy and political security of both countries, of course the answer is yes. From their recent cooperation, its bring a lot of positive impact for both countries but we still need to increase for a greater and biggest collaboration for getting maximal outcomes not only for economy and political security but also in the other aspect also.

ASEAN and Russia can maintain and increase their bilateral relation rapidly if they paid attention for the outcome of this relationship. In economic aspect, assessing prospects for a Free Trade Agreement with ASEAN countries one must consider the level of their trade restrictions. The higher an import tariff in a given country, the larger the preferential margin is to a country that sets up a

\footnotetext{
${ }^{10}$ Sergei Blagov "Sochi ASEAN summit: Russia eyes economic expansion in SE Asia" from http://atimes.com/2016/05/sochi-asean-summitrussia-eyes-economic-expansion-in-southeast-asia/ was access in Asia times news and features, Southeast Asia on 23 May 2017
}

free trade with it. The extent of complementariness of trade with a potential trading partner is another key criterion used to set up an FTA. The larger it is the lower the costs of competition between producers in the two countries. With this idea, it can be increase the economic relation in both countries and the GDP also will be grown. In political security, Russia can be dependent actors and play a third role parties as the mediator and help to solve many regional conflict in member countries of ASEAN.

Both parties must take a chance and utilize the ASEAN forum in Sochi in 2016 as the important chance to talk more and build agreement in Politics and Political security. In that forum both parties must be discussing about a long-term project and how Russia can intervene more in the regional conflict in ASEAN member countries like their intervention in Syria and bring much more stabilization between people and government there. Russia success bombings many camp of ISIS in Syria. With the support of Russia military control, each member countries of ASEAN can control their security and increase their technology and military. Security always is the main objectives of peaceful countries in all around the world. The Ministry of Defence of ASEAN Plus said that involving Russia, India, China, and the US will help the Infrastructure in ASEAN especially the countries with most conflict happen.

In the trade agreement, both parties must include free trade agreement and the minimal product for export to each other, give a strict regulation if one country obeys to export because it was only give advantage for one parties if only one parties active for selling their product. Discussion is the best way to resolve the dispute. Under the UN Charter and the UN Convention on the Law of the Sea, Trakat Friendship and Cooperation of Southeast Asia, we have to 
resolve this issue peacefully. We must implement these principles, and did not lose their way.

We do hope that fair multilateral cooperation will be the focus of all countries. For example, some critics said that Russia only focus on Vietnam as their longest and biggest investment cooperation and another country is not their main partnership. It was announced during the Sochi summit that ASEAN would consider a free trade agreement (FTA) with the Russia-let Eurasian Economic Union (EEU). Last year, the EEU signed a free trade agreement with one ASEAN member-state, Vietnam. Russia is so famous with their political security aspect and all ASEAN country must be learn and take this as a chance to do the bilateral relation in this aspect.

\section{Conclusion}

Relations with ASEAN have never been a top priority in Russia's Asian policy. Neither Russia nor ASEAN regards each other as number one partner because both parties still have the top priority actors as doing cooperation like European Union, China or US but as Viktor Sumsky says, both Russia and ASEAN have enough to offer one another in terms of political, economic, and cultural cooperation. What is still missing on both sides is the real sense of the other's importance as a partner. In the last several years, Russia expanded their mark to South East Asia. It is not only oil and gas exploration that Russian companies focused, as we know that Russia is very famous with their oil and gas system and they had a lot of big companies, these company also assisting
Indonesia, Vietnam, Cambodia, and Laos in building the necessary energy infrastructure. ${ }^{11}$

ASEAN-Russia cooperation gives many advantage in both sides, economy and political security issue are the main issue in both countries. Russia tries gain the interest and look for the new parties in eastern countries like Asia and especially ASEAN. Mutual benefits for all the both sides make their bilateral relation growing all the years. Talking, buying and selling of goods, and signing agreements and MOUs are the characteristics of the interactive world we know. In the knowledge-based economy of the new global village, exchange of information and innovation of the way we work is the key to advance mutual benefit. The balance of interests and a win-win solution determine how our cooperation moves ahead. ASEAN and Russia have built up a stable foundation of partnership in the past 10 years. The prospect of strong progress is good. With the ASEAN, Economic Community, more opportunities are available and Russia can benefit from this development as Russian business expands its involvement in Southeast Asia.

Russia always towards the more stability economic system until now, the stereotype of Russia as the Soviet Union and as the country which is not depend and the enemy of all countries is not anymore. Russia can be the most powerful country which is towards globalization and create much cooperation in another country. BRICS are one of the international organizations of the successful of Russia. ASEAN still have many jobs to do in the future. The cooperation

\footnotetext{
11 Elena S Martynova "Strengthening of Cooperation Between Russia and ASEAN: Rhetoric or Reality?" by Asian Politics \& Policy-Volume 6, Number 3Pages 397-412 (C) 2014 Policy Studies Organization. Published by Wiley Periodicals, Inc. access on https://www.hse.ru/pubs/share/direct/document/14410 6129
} 
between each member is important to gain the attention for international level competition.

ASEAN is an international organization which is they must have a significant impact to the domestic violence happen in all countries. ASEAN try to make cooperation with other countries which is not ASEAN member itself because it can be a good chance for making a better political system and towards the world governance. ASEAN can learn for how the other countries success to stop the violence and make the better world for everybody. Military Dictatorship was very common in most of the countries, because it processed the strong authoritarian rule needed to counter communism. External conflict lays solely on the threat from Vietnam, while an internal conflict was on the communist influences domestically that were big threats creating fragmentation in each country. ASEAN can be the most powerful association and international organization if they keep maintain a good economy progress, increase the social-culture cooperation between each member and maintain a peace in political and security to each member countries. ASEAN also have their own identity and maintain each member ideology without intervention from other countries.

We are looking for their next cooperation and as citizens of ASEAN and now study in Russia I believe that this collaboration will give a good advantage in both sides and increase the economic and towards the peace building in political and security aspect. In the future, we can see that their trade statistic will always improve and Russia can be the mediator in regional conflict in each ASEAN member countries.

\section{References}

\section{Journal:}

Rangismaporn, P. (2009), 'Russia's Search for Influence in Southeast Asia', Asian Survey 49 (5), 786-808.

\section{Website:}

www.asean.org

ASEAN Charter

ASEAN-Russia Dialogue Partnership from http://asean.org/?static_post=aseanrussia-dialogue-relations was published on 15 May 2012

Alexander Korablinov. "Russia, ASEAN hail growing trade ties" RBTH from http://asia.rbth.com/international/2015/08/ 04/lavrov_to_discuss_economic_cooperati on_with_asean_fms_48251.html on 26 August 2015

Aleksey Druzhinin. TASS "Putin: RussiaASEAN Summit to help solve regional security problems" from http://tass.com/politics/874929 was published on May 11, 2016, 13:17

Alexey Timofeychev. "Sergey Lavros pushes for greater Russia-ASEAN ties" RBTH from http://rbth.com/international/2015/08/10/s ergey_lavrov_pushes_for_greater_russiaasean_ties_48365.html on August 102015 by

Aleksander Ilyutochkin. "Tiga Bidang yang Memperkuat Kerja Sama Russia Indonesia” RBTH Indonesia from http://indonesia.rbth.com/economics/2015/ 10/20/tiga-bidang-yang-memperkuatkerja-sama-rusia-indonesia_484557 on 20 October 2015 
Elena S Martynova. "Strengthening of Cooperation Between Russia and ASEAN: Rhetoric or Reality?" by Asian Politics \& Policy-Volume 6, Number 3-Pages 397-412 (C) 2014 Policy Studies Organization. Published by Wiley Periodicals, Inc. access on https://www.hse.ru/pubs/share/direct/docu ment/144106129

Mohamad Rosyidin. "ASEAN and Russia: Creating a New Security Architecture" from http://thediplomat.com/2016/06/aseanand-russia-creating-a-new-securityarchitecture/ on 1 June 2015

Sergei Blagov. "Sochi ASEAN summit: Russia eyes economic expansion in SE Asia" from http://atimes.com/2016/05/sochiasean-summit-russia-eyes-economic- expansion-in-southeast-asia/ was access in Asia times news and features, Southeast Asia on 23 May

Sergei Lavrov. "Russia and ASEAN can achieve a great deal together" from https://interaffairs.ru/i/pdf_asean/2.pdf special issue on 2010

Wikipedia. "History of Russia 1991-present" was last edited on 6 September 2017, at 15:09

Yaroslav Lisovolik D.Sc. (Econ.), Professor at the Foreign Economic Affairs and International Business Chair, Diplomatic Academy of the Ministry of Foreign Affairs of the Russian Federation "IS A RUSSIA-ASEAN FREE TRADE AREA OF ANY USE?" by http://asean.mgimo.ru/images/partn/Lissov olik_FTA_en.pdf. 